\title{
MICROFOSSILS AS INDICATORS OF SEA-LEVEL CHANGE IN CRETACEOUS SHALES OF WESTERN CANADA
}

SCHRÖDER-ADAMS*, Claudia J., Dept. of Earth Sciences, Carleton Univ., Ottawa, Ontario, K1S 5B6, Canada; LECKIE, Dale A., Geological Survey of Canada, 330333st NW, Calgary, Alberta, T2L 2A7, Canada; CRAIG, Jim, Box 668, Bragg Creek, Alberta, TOL OK0, Canada.

Sequence stratigraphic boundaries in regional basin analysis of the Western Interior Seaway can be defined by microfossils. Marine shales in the Colorado Group of Western Canada were deposited during the mid-Cretaceous third-order eustatic rise in sea level with superimposed tectonic fourth and fifth-order sea-level fluctuations. Sea level began rising with a mid-Albian flooding event, and reached its maximum depth during the Turonian. Shales represent deposition of the late Albian Westgate Formation, the early Cenomanian Fish Scales Formation, the middle to late Cenomanian Belle Fourche Formation and the latest Cenomanian to middle Turonian Second White Specks Formation.

Foraminiferal and nannofossil assemblages indicate dynamic oceanographic conditions linked to sea-level change, and document two anoxic bottom-water events. During oxic bottom-water conditions, agglutinated foraminifera are common and mainly facies-controlled, showing correlation with parasequences. Progradational cycles within the highstand system tracts of the Westgate and Belle Fourche formations are characterized by dominantly agglutinated foraminifera of different species diversity and composition. Plankton is only represented by dinoflagellates, whereas planktic foraminifera and coccoliths are absent.

Two condensed sections (Fish Scales and Second White Specks formations) have numerous similarities but also exhibit significant differences. Both are characterized by sharp basal contacts marking marine erosion surfaces. The basal contact of the Fish Scales Formation is expressed by a bioclastic layer and basinwide disappearance of all agglutinated foraminifera. The faunal transition at the basal contact of the Second White Specks Formation varies. The presence of a bioclastic layer formed by deep marine erosion is connected with an abrupt change from a diminished agglutinated fauna to a pelagic fauna (abundant planktic foraminifera and nannofossils). The degree of erosion at the unconformity varies across the basin, being greatest in central Saskatchewan. Other localities show a more transitional faunal change from benthic to planktic assemblages. The upper contact of the Fish Scales Formation is gradational. Bottom anoxia inhibited benthic foraminifera during the lower Cenomanian. Conditions changed gradually, enhancing a low diversity agglutinated fauna of the overlying Belle Fourche Formation indicating dysoxia. The abrupt upper contact of the Second White Specks Formation is marked by sudden disappearance of all planktic foraminifera and nannofossils.

The Westgate Formation is characterized by multiple shoaling upwards successions (parasequences?), each overlain by a flooding surface. Agglutinated foraminiferal tests respond to changes in substrate conditions with grain size differences correlating with facies changes in coarsening-up cycles. Species composition varies slightly, however, several species are able to adapt with finer or coarser tests to sediment grain size variations. 